\title{
Tanggung Jawab Iran terhadap Penembakan Pesawat Sipil Ukraina Ditinjau dari Hukum Udara Internasional
}

\author{
Nabila Indriana Hasibuan*; Retno Kusniati \\ Fakultas Hukum, Universitas Jambi \\ *Coresponding author: indriananabila30@gmail.com
}

$\begin{array}{ll}\text { Submission } & : \text { 30 Juli } 2020 \\ \text { Revision } & : \text { 31 Oktober } 2020 \\ \text { Publication } & : \text { 23 November } 2020\end{array}$

\begin{abstract}
The purpose of this research were to find out and analyze Iran's responsibility for shooting Ukrainia's civil aircraft in international air law. The problem that will be discussed is the regulation in international law about the state's obligation for manage civil aviation safety that trough their territory and Iran's responsibility for shooting Ukrainia's civil aircraft in international law. The type that used for this research is normative legal research, the approach in this study is law approach, case approach and historical approach, the sources of legal material used are primary, secondary, and tertiary legal materials. The result of the study show that (1) states whose its airspace passed by civil aircraft must guarantee the aircaft safety in a way regulate the prohibited area if something happen in the territory and the aircraft cant pass through and with a great air navigation civil aircraft safety and security can be guaranteed well. (2) Iran must take full responsibility of this shooting because Iran did not regulate the prohibited area during the conflict. In the future, it is necessary to emphasize the state's responbility for the route for internationl civil aviation and cooperate with other parties so that safety and security on international aviation can be achhieved.
\end{abstract}

\section{Keywords: Civil Aircraft; International Air Law; State Responsibility}




\begin{abstract}
Abstrak
Penelitian ini bertujuan untuk menganalisis pertanggungjawaban negara Iran atas tertembaknya pesawat sipil Ukraina dalam Hukum Udara Internasional. Rumusan masalah yang dibahas adalah pengaturan hukum udara internasional terkait kewajiban para pihak untuk mengatur keselamatan penerbangan sipil yang melewati wilayah udaranya serta tanggung jawab negara Iran terhadap penembakan pesawat sipil Ukraina ditinjau dari Hukum Internasional. Jenis penelitian yang digunakan adalah jenis penelitian hukum normatif, maka pendekatan dalam penelitian ini adalah pendekatan perundang-undangan (statute approach), pendekatan kasus (case approach), dan pendekatan sejarah (historical approach), sumber bahan hukum yang digunakan yaitu bahan hukum primer, sekunder, dan tersier. Hasil penelitian menunjukan bahwa (1) Negara yang wilayah udaranya dilewati oleh pesawat sipil harus menjamin keselamatan pesawat sipil tersebut dengan cara menetapkan zona larangan terbang apabila di wilayah udara negara tersebut sedang terjadi sesuatu dan tidak memungkinkan untuk dilewati oleh pesawat sipil serta memberikan navigasi penerbangan yang jelas sehingga dapat menjamin keselamatan dan keamanan pesawat sipil yang melewati wilayah udara negara tersebut. (2) Iran harus bertanggung jawab penuh atas terjadinya penembakan ini dikarenakan tidak menetapkan zona larangan ketika sedang berkonflik. Di masa yang akan datang perlu ditegaskan pertanggungjawaban negara atas jalur rute penerbangan sipil internasional serta meningkatkan kerja sama dengan berbagai pihak agar keselamatan dan keamanan dalam penerbangan internasional bisa tercapai
\end{abstract}

\title{
Kata Kunci: Hukum Udara Internasional; Pesawat Sipil; Tanggung Jawab Negara
}

\section{A. Pendahuluan}

Pengaturan mengenai penerbangan sipil internasional telah diatur dalam berbagai Konvensi internasional. Dalam hukum udara internasional publik terdapat Konvensi Chicago Tahun 1944 yang berisi tentang beberapa ketentuan pengangkutan udara Internasional yang merupakan norma penerbangan sipil internasional. Konvensi tersebut dijadikan sebagai standar dalam pembuatan hukum nasional bagi negara anggota 
Organisasi Penerbangan Sipil Internasional (International Civil Aviation Organization). Keberadaan ICAO di komunitas internasional menjadi signifikan mengingat industri penerbangan mempromosikan dan memprioritaskan elemen teknologi canggih dan terkait dengan kehidupan manusia. Bahkan, materi pelajaran dalam hukum penerbangan adalah konsep luas yang mensinergikan peraturan nasional dan hukum internasional. Hal tersebut disebabkan oleh berbagai hal aspek hukum yang relevan dengan penggunaan wilayah udara seperti masyarakat dan lingkungan alami suatu negara ${ }^{1}$

Prinsip dasar hukum udara internasional adalah bahwa setiap negara memiliki kedaulatan yang lengkap dan eksklusif atas wilayah udara di atas wilayahnya, termasuk laut teritorialnya. Pada pergantian abad ke-20, pandangan bahwa wilayah udara, seperti laut lepas, harus bebas terkadang dikembangkan. Tetapi prinsip kedaulatan wilayah udara dengan tegas ditegaskan dalam Konvensi Paris tentang Peraturan Navigasi Udara (1919) dan kemudian oleh berbagai perjanjian multilateral lainnya. Prinsip tersebut dinyatakan kembali dalam Konvensi Chicago tentang Penerbangan Sipil Internasional. Wilayah udara sekarang secara umum diterima sebagai kelengkapan dari wilayah penaklukan dan berbagi status hukum yang terakhir.

Jadi, di bawah Konvensi Jenewa tentang Laut Lepas (1958) serta di bawah hukum kebiasaan internasional, kebebasan laut lepas berlaku untuk navigasi udara serta navigasi laut. Secara vertikal, ruang udara berakhir di mana ruang angkasa dimulai. Sesuai dengan prinsip kedaulatan wilayah udara bahwa setiap negara berhak mengatur masuknya pesawat asing ke dalam wilayahnya dan bahwa orang-orang di dalam wilayahnya tunduk pada hukumnya.

${ }^{1}$ Andika Immanuel Simatupang. State Responsibility Over Safety And Security On Air Navigation Of Civil Aviation In International Law. Jurnal Hukum Internasional. Vol 13. No 2. 2016. hal 275. 
Negara biasanya mengizinkan pesawat swasta asing (yaitu, nonpemerintah dan nonkomersial) untuk mengunjungi atau terbang melalui wilayah mereka tanpa terlalu banyak kesulitan. Berdasarkan Konvensi Chicago, negara-negara yang mengadakan kontrak setuju untuk mengizinkan pesawat yang terdaftar di negara bagian lain yang mengadakan kontrak dan terlibat dalam penerbangan komersial tidak terjadwal untuk terbang ke wilayah mereka tanpa izin diplomatik sebelumnya dan, terlebih lagi, untuk mengambil dan menurunkan penumpang, kargo, dan surat, tetapi dalam praktek ketentuan ini sudah menjadi surat mati.

ICAO sebagai lembaga internasional dalam bidang penerbangan menetapkan protokol untuk investigasi kecelakaan udara yang diikuti oleh otoritas keselamatan transportasi di negara-negara yang menandatangani Konvensi Chicago tentang Penerbangan Sipil Internasional. ${ }^{2}$ Kegiatan ICAO telah termasuk menetapkan dan meninjau standar teknis internasional untuk operasi dan desain pesawat, investigasi kecelakaan, lisensi personel, telekomunikasi, meteorologi, peralatan navigasi udara, fasilitas darat untuk transportasi udara, dan misi pencarian dan penyelamatan. Bagian Investigasi Kecelakaan (AIG) ICAO bertanggung jawab untuk mengembangkan dan memperbarui Standar dan Praktik yang Direkomendasikan (SARP) untuk dimasukkan dalam Lampiran 13 - Investigasi Kecelakaan dan Insiden Pesawat Udara; memantau perkembangan teknik dan praktik investigasi kecelakaan serta hal-hal pencegahan kecelakaan; memantau perkembangan dalam konsep dan praktik keselamatan sistem, berkontribusi pada ICAO Global Aviation Safety Plan dan ICAO Universal Safety Oversight Audit Program (USOAP); mengelola rekomendasi keselamatan yang ditujukan kepada ICAO;

\footnotetext{
${ }^{2}$ https://en.wikipedia.org/wiki/International_Civil_Aviation

Organization diakses pada 23 Februari 2020 pukul 22.26 WIB
} 
melakukan dan berpartisipasi dalam seminar tentang investigasi dan pencegahan kecelakaan pesawat.

Bagian AIG memberikan panduan tentang mata pelajaran berikut:

- investigasi kecelakaan dan insiden pesawat;

- pelatihan untuk penyelidik kecelakaan pesawat;

- bahaya di lokasi kecelakaan pesawat;

- bantuan untuk korban kecelakaan pesawat dan keluarganya;

- kebijakan dan prosedur investigasi kecelakaan dan insiden; dan

- organisasi investigasi kecelakaan dan insiden regional. $^{3}$

Organisasi ini juga mempromosikan perjanjian regional dan internasional yang bertujuan meliberalisasi pasar penerbangan, membantu menetapkan standar hukum untuk memastikan bahwa pertumbuhan penerbangan tidak membahayakan keselamatan, dan mendorong pengembangan aspek-aspek lain dari hukum penerbangan internasional. ${ }^{4}$

Unifikasi hukum mengenai penerbangan sangat penting dalam penerbangan internasional, hal ini karena dalam penerbangan-penerbangan internasional akan melewati beberapa wilayah negara asing yang memiliki hukummaupun tidak, kemudian penumpang didalam pesawat juga memiliki kewarganegaraan yang beragam, sehingga dengan dilakukannya unifikasi hukum mengenai penerbangan sipil apabila sewaktu-waktu terjadi permasalahan seperti kejadian penembakan pesawat udara sipil antar lain kita dapat lihat kejadian jatuhnya maskapai penerbangan Malaysia Air Lines MH17.

\footnotetext{
${ }^{3}$ https://www.icao.int/safety/airnavigation/AIG/Pages/default.aspx

${ }^{4}$ Karen Mingst. International Civil Aviation Organization. Diakses dari https://www.britannica.com/topic/International-Civil-AviationOrganizationdiakses pada 23 Februari 2020 pukul 23.06 WIB
} 
Pesawat Malaysia Airlines MH17 yang menglami kecelakaan pada tanggal 17 Juli 2014 lalu dikarenakan menjadi sasaran penembakan rudal dan menyebabkan korban jiwa yang tidak sedikit. ${ }^{5}$ Dalam hal penembakan pesawat sipil menggunakan rudal juga terjadi baru-baru ini. Tepatnya pada hari Rabu, 8 Januari 2020 pesawat sipil milik Ukraina dengan pesawat maskapai Ukrainian International Airlines yang ditembak oleh Iran menggunakan rudal ketika melewati kawasan sensitif di sekitar markas Garda Revolusi Iran. ${ }^{6}$ Pesawat jenis Boeing 737-800 jatuh sesaat setelah lepas landas dari Bandara Internasional Imam Khomeini di Teheran. Jatuhnya pesawat sipil ini menyebabkan 176 penumpangnya meninggal dunia. ${ }^{7}$

Iran mengeluarkan pernyataan resminya, dan Iran menyebut peristiwa itu terjadi akibat kesalahan manusia. Alasannya, pesawat maskapai Ukrainian International Airlines melintasi kawasan sensitif di sekitar markas Garda Revolusi Iran. Kemudian angkatan bersenjata Iran juga menyebut akan menindak para pihak yang bertanggung jawab atas kejadian itu secara transparan. ${ }^{8}$

Negara sebagai subjek hukum internasional dapat dimintakan tanggung jawab ketika suatu negara tidak

5 Arland Yoga. Peran International Civil Aviation Organization dalam Penanganan Kasus Penembakan Penerbangan Sipil Internasional Studi Kasus: Penembakan Pesawat Malaysia Airlines MH17 Tahun 2014. Jurnal Hubungan Internasional,Vol 4 No. 2,2018 hlm. 242

6 Tim BBC Indonesia. Penembakan pesawat Ukraina, media Iran: 'Malu' dan 'tak termaafkan. Diakses dari https://www.bbc.com/indonesia/dunia-51081065. diakses pada 30 Januari 2020 pukul 09.52 WIB.

7 Tim Detik News,'Presiden Iran: Penembak Jatuh Pesawat Sipil Ukraina Bakal Dihukum Berat", diakses dari https://news.detik.com/internasional/d-4855221/iran-tak-sengajatembak-jatuh-pesawat-sipil-ukraina-ini-kata-pm-kanada. diakses pada 30 Januari 2020 pukul 20.30 WIB.

${ }^{8}$ Ibid 
melaksanakan kewajiban, telah melakukan tindakan-tindakan kelalaian yang melawan hukum. Negara berkewajiban untuk tidak menyalah gunakan kedaulatan itu sendiri, ketika suatu negara menyalah gunakan kedaulatannya, maka negara tersebut dapat diminta suatu pertanggungjawaban atas tindakan dan kelalaiannya. ${ }^{9}$

Iran yang mana dalam tragedi ini merupakan negara kolong yang harus bertanggung jawab atas kasus penembakan di dalam wilayah kedaulatan udaranya. ${ }^{10}$ Berdasarkan permasalahan diatas, maka penulis tertarik untuk menelaah permasalahan tersebut ke dalam sebuah penelitian yang berjudul "Tanggung Jawab Negara Iran Terhadap Tertembaknya Pesawat Sipil Ukraina Ditinjau Dari Hukum Udara Internasional".

\section{B. Metode Penelitian}

Jenis penelitian yang digunakan dalam penelitian ini adalah penelitian hukum normatif, dimana penelitian ini berangkat adanya isu hukum. Penelitian hukum dilakukan untuk menghasilkan argumentasi, teori, atau konsep baru sebagai preskripsi dalam menghadapi masalah yang dihadapi. Penelitian hukum normatif merupakan jenis penelitian hukum yang diperoleh dari studi kepustakaan, dengan menganalisis suatu permasalahan hukum melalui peraturan perundangundangan, literatur-literatur dan bahan-bahan referensi lainnya. Dalam penelitian tipe normatif, yaitu penelitian yang dilakukan dengan cara mengkaji, mendeskripsikan, mensistemasikan, menginterprestasikan, menilai, dan menganalisis hukum positif. ${ }^{11}$ Penelitian normatif merupakan penelitian hukum yang dilakukan dengan cara meneliti bahan

\footnotetext{
9 Tim BBC Indonesia. op cit.

10 Tim Detik News. op cit.

11 Bahder Johan Nasution. Metode Penelitian Ilmu Hukum. Cet. 2. Mandar Maju. Bandung. 2016. hal. 80.
} 
pustaka atau data sekunder. ${ }^{12}$ Kemudian penelitian ini akan dilakukan dengan menggunakan bahan kepustakaan melalui berbagai literatur yang berhubungan dengan hukum udara internasional.

\section{Pembahasan dan analisis}

Pembahasan dan analisis bertujuan untuk menjawab rumusan masalah dan pertanyaan-pertanyaan penelitian, menunjukkan bagaimana temuan-temuan diperoleh, menerangkan arti hasil penelitian, bagaimana hasil penelitian dapat memecahkan masalah serta kemungkinan pengembangannya. Pembahasan dan analisis harus menjawab permasalahan dan tujuan penelitian.

\section{Kewajiban Para Pihak Untuk Mengatur Keselamatan Penerbangan Sipil dalam Konvensi Chicago 1944.}

Kedaulatan Negara adalah prinsip dasar hukum internasional. Namun, istilahnya adalah sangat sering digunakan dalam pengertian politik, dengan interpretasi yang berbeda tergantung pada konteks dan maksudnya. Pengertian tentang kedaulatan bersifat dinamis, berkembang dengan perkembangan lingkungan kelembagaan global. Dalam penerbangan, kedaulatan mengacu pada kepemilikan wilayah udara. Dengan kata lain, kompetensi eksklusif sebuah Negara untuk menjalankan kekuasaan legislatif, administratif dan yudikatifnya di dalam wilayah udara nasionalnya. Dalam pembukaan Konvensi Chicago 1944 Tentang Penerbangan Sipil Internasional dijelaskan bahwa perkembangan penerbangan sipil di masa yang akan datang dapat digunakan

Soerjono Soekanto. Peneitian Hukum Normatif : Suatu Tinjauan Singkat. PT. Raja Grafindo Persada. Jakarta. 2003. hal 13 
untuk meningkatkan persahabatan, mencegah konflik, kerja sama antar bangsa serta memelihara perdamaian dunia. ${ }^{13}$

Sejalan dengan lahirnya konsep diatas maka konvensi ini didasarkan pada prinsip kedaulatan negara penuh dan eksklusif atas ruang udara. Seperti hal nya pada Pasal 1 Konvensi Chicago 1944 yang berbunyi "The contracting States recognize that every state has complete and exclusive sovereignty over the airspace above its teritory". Kedaulatan negara yang complete dan exclusive merupakan kodifikasi dari hukum kebiasaan Internasional yang telah digunakan sejak dulu di Eropa dan sekarang telah diterima oleh Negara-Negara di dunia saat ini. Sifat universal pada Pasal 1 Konvensi Chicago 1944 dapat ditelaah dari penggunaan "every states" untuk menyebutkan bahwa kedaulatan dan kekuasaan para pihak atas wilayah udara di atasnya dimiliki oleh semua negara bukan hanya negara pihak konvensi ini saja. Sifat kedaulatan di udara seperti yang ada dalam Pasal 1 berbeda dengan kedaulatan negara tentang perairan. Jika dalam wilayah udara negara memiliki kedaulatan penuh sementara dalam perairan kedaulatan negara di laut territorial dibatasi dengan hak negara lain untuk melakukan hak lintas damai (innocent passage). Akibat dari Pasal ini dalam bidang pertahanan juga terjadi perbedaan antara kedaulatan udara dengan kedaulatan perairan. ${ }^{14}$

Salah satu cara negara kolong atau negara para pihak melindungi pesawat udara yang melewati wilayah udaranya adalah menetapkan Zona larangan terbang. Zona larangan

13 Ratih Puput Prasetyani.Analisis Yuridis Terhadap Tanggung Jawab Negara Ukraina Atas Jatuhnya Pesawat Malaysia Airlines MH17 Ditinjau Dari Hukum Udara Internasional. Skripsi Sarjana Fakultas Hukum Universitas Brawijaya. 2015. hal 24.

14 Endang Puji Lestari.Rekonsepsi Hak Penguasaan Negara Atas Wilayah Udara Di Tengah Kebijakan Liberalisasi Penerbangan. Jurnal Rechts Vinding. Volume 4 Nomor 2. Agustus 2015. 
terbang diatur dalam Pasal 9 Konvensi Chicago 1944 yang berbunyi sebagai berikut :

a. Each contracting state may, for reason of military necessity or public safety, restrict or prohibit uniformly the aircraft of other states from flying over certain areas of its teritory, provided that no distinction in this respect is mae between the aircraft of the state whose territory is involved, engaged in international scheduled airlines service, and the aircraft of the other contracting states likewise engaged. Such prohibited area shall reasonable extent and location so as not to interference unnecessarily with navigation. Description of such prohibited areas in the territory of contracting states, as while as any subsequent alteration therein shall be communicated as soon as possible to the other contracting states and to international civil aviation organization.

b. Each contracting states reserves also the right, in exceptional circumtanses or during a period of emergency, or in the interest of public safety, and with immediate effect, temporary to restrict or prohibit flying over the wholeor any part in its territory, on condition that such ristriction or prohibition shall be applicable without distinction

c. Each contracting states, under such regulation as it may prescribe, may require any aircraft entering the areas contemplated in the subparagraph (a) or (b) above to effect a landing as soon as praticable there after at some designated airport within its territory.

Pasal 9 Konvensi Chicago menetapkan bahwa Setiap Negara yang terikat kontrak dapat, karena alasan kebutuhan militer atau keselamatan publik, membatasi atau melarang secara seragampesawat dari Negara lain untuk terbang di atas area tertentu di wilayahnya, asalkan tidak ada perbedaan 
dalam penghormatan ini dibuat antara pesawat udara Negara yang wilayahnya terlibat, terlibat dalam layanan-layanan penerbangan berjadwal internasional, dan pesawat udara dari Negara-negara penandatangan lainnya yang juga terlibat area terlarang tersebut harus memiliki luas dan lokasi yang wajar agar tidak mengganggu navigasi udara yang tidak perlu. Menurut Pasal 9 diatas Negara anggota berhak menetapkan zona larangan atas pertimbangan keamanan masyarakat umum. Kemudian dikarenakan militer, asalkan tidak ada diskriminasi antar pesawat udara nasional dengan asing ataupun terhadap sesama pesawat asing.

Penetapan zona larangan harus dilakukan dengan semestinya dan tidak mengganggu penerbangan apalagi kedamaian internasional. Perihal tentang zona larangan harus segera diberitahukan pada Organisasi Penerbangan Sipil Internasional secara jelas. Dalam keadaan darurat serta keselamatan umum negara anggota juga berhak melarang seluruh maupun sebagian wilayah udaranya agar tidak dilewati asalkan tidak bersifat diskriminatif. Zona larangan terbang yang telah diatur pada pasal 9 Konvensi Chicago 1944 merupakan salah satu bentuk antisipasi atas ancaman yang dapat membahayakan penerbangan sipil lintas negara. Penentuan zona terlarang tersebut di wilayah suatu Negara pihak pada persetujuan, serta yang berikutnya amandemennya, harus dilaporkan kepada Negara pihak pada persetujuan lainnya dan Penerbangan Sipil Internasional Organisasi sesegera mungkin. ${ }^{15}$

Dalam teori kepemilikan ruang udara (The Air Sovereignty Theory) ketentuan tentang kedaulatan yang

15 Ewa Jasiuka. The responsibility of a State in the shooting down of Malaysian Airlines flight MH17, 8th International Conference on Air Transport - INAIR 2019 GLOBAL TRENDS IN AVIATION. 2019. hal 117. 
dimiliki negara kolong ${ }^{16}$ terhadap pengangkut komersial yang melintasi wilayah ruang udara terdiri dari;

a. Negara kolong berdaulat penuh hanya terhadap satu ketinggian tertentu di ruang udara;

b. Negara kolong berdaulat penuh, tetapi dibatasi oleh hak lintas damai bagi navigasi pesawat -pesawat udara asing, dan;

c. Negara kolong berdaulat penuh tanpa batas. Berdasarkan teori diatas maka dapat diambil suatu garis besar bahwa negara kolong berdaulat penuh atas wilayah udaranya, sehingga setiap pengangkut komersial yang melintasi wilayah udaranya dapat terjamin keselamatan dan keamanan penerbangannya. ${ }^{17}$

Secara hukum udara internasional berlandaskan kepada doktrin kedaulatan, setiap Negara berhak mengatur segala sesuatunya yang berkaitan dengan keamanan negaranya, keamanan penerbangan bagi setiap penerbangan udara di wilayahnya hal ini diatur dalam Pasal 12 Konvensi Chicago 1944 yang berbunyi :

"Each contracting State undertakes to adopt measures to insure that every aircraft flying over or maneuvering within its territory and that every aircraft carrying its nationality mark, wherever such aircraft may be, shall comply with the rules and regulations relating to the flight and maneuver of aircraft there in force. Each contracting State undertakes to keep its own regulations in these respects uniform, to the greatest possible extent, with those established from time to time under this Convention. Over the high seas, the rules in force shall be

16 Negara kolong adalah negara-negara yang tepat berada di bawah garis khatulistiwa yang wilayahnya juga merupakan wilayah negara yang berada tepat di bawah kawasan $\mathrm{GSO}($ Geo-Stationary Orbit).

17 Baiq Setiani. Konsep Kedaulatan Negara di Ruang Udara dan Upaya Penegakan Pelanggaran Kedaulatan oleh Pesawat Udara Asing. Jurnal Konstitusi. Volume 14. Nomor 3. September 2017. 
those established under this Convention. Each contracting State undertakes to insure the prosecution of all persons violating the regulations applicable"

Pesawat udara yang melewati suatu wilayah Negara harus mematuhi aturan mengenai penerbangan di Negara tersebut. Aturan dalam penerbangan sipil berlaku jika melewati wilayah udara negara kolong adalah hukum nasional negara kolong tersebut, kecuali pesawat udara yang melewati laut lepas maka yang berlaku adalah hukum internasional seperti yang diatur dalam Konvensi Chicago 1944.

Setiap negara anggota berhak membuat peraturan yang berlaku di negaranya, ditujukan pada penerbangan nasional maupun internasional yang berasal atau ke negara tersebut. Tetapi peraturan itu harus bisa berlaku terhadap semua pesawat udara nasional maupun internasional. Kemudian negara juga harus mempertimbangkan keamanan penerbangan sipil internasional. Karena itu dibutuhkan adanya peraturan yang seragam agar dapat mencangkup segalanya dalam penerbangan sipil internasional. ${ }^{18}$

Kemudian pada Pasal 28 Konvensi Chicago 1944 yang berisi tentang pelayanan navigasi udara jelas merupakan tanggung jawab Negara yang bersumber dari konsep kedaulatan di udara. Navigasi udara ini merupakan hal yang penting untuk mencegah terjadinya kecelakaan di wilayah udara. Sekaligus agar dapat menjaga keselamatan pesawat udara yang melewati wilyah Negara tersebut. Pasal 28 berisi sebagai berikut :

Each contracting State undertakes, so far as it may find practicable, to:

18 Ratih Puput Prasetyani.Analisis Yuridis Terhadap Tanggung Jawab Negara Ukraina Atas Jatuhnya Pesawat Malaysia Airlines MH17 Ditinjau Dari Hukum Udara Internasional. Skripsi Sarjana Fakultas Hukum Universitas Brawijaya. 2015. hal 25. 
a) Provide, in its territory, airports, radio services, meteorological services and other air navigation facilities to facilitate international air navigation, in accordance with the standards and practices recommended or established from time to time, pursuant to this Convention;

b) Adopt and put into operation the appropriate standard systems of communications procedure, codes, markings, signals, lighting and other operational practices and rules which may be recommended or established from time to time, pursuant to this Convention;

c) Collaborate in international measures to secure the publication oaeronautical maps and charts in accordance with standards which may be recommended or established from time to time, pursuant to this Convention.

Pesawat udara yang melewati suatu wilayah Negara harus mematuhi aturan mengenai penerbangan di Negara tersebut. Negara tersebut berjanji untuk menjaga keseragaman peraturan penerbangan yang ada di Negaranya. Tanggung jawab berdasarkan Pasal 28 Konvensi Chicago tetap dengan peraturan keselamatan dan keamanan haruslah dihormati oleh pesawat yang melewati wilayah tersebut. ${ }^{19}$

Serta berdasarkan Pasal 28 negara berkewajiban memberikan pelayanan keselamatan penerbangan sipil berupa pelayanan navigasi penerbangan, sehingga harus memberikan keselamatan dan keamanan atas kedaulatan ruang udara di atas wilayahnya yang dilewati oleh pesawat yang melintas dengan mengikuti standar dan rekomendasi yang ada (SARP). Peraturan terkait mengenai standar dan rekomendasi dalam penerbangan sipil diatur dalam Pasal 37 dan 38 Konvensi Chicago.

19 Baiq Setiani. Op. Cit.

Uti Possidetis: Journal of International Law, Vol. 1, No. 3 (2020) 
Serta dalam hal Penerapan aspek yurisdiksi negara terhadap pesawat udara yurisdiksi suatu negara dapat dikatakan sebagai suatu kewenangan hukum yang dilaksanakan oleh negara sebagai implementasi dimilikinya suatu kedaulatan. Dalam hal ini, adanya suatu kebebasan menentukan kewenangannya berkaitan dengan peraturan yang berlaku mengenai kewajiban pesawat udara sipil harus didaftarkan di suatu negara. Dimana negara-negara yang dijadikan tempat pesawat udara sipil didaftarkan bebas untuk membuat sendiri peraturan yang berkaitan dengan persyaratan serta prosedur dilakukannya pendaftaran pesawat udara sipil. Akan tetapi, peraturan yang dibuat oleh negara-negara tersebut harus tetap mengacu kepada Konvensi Chicago 1944 yang menjadi tolak ukur peraturan penerbangan secara internasional. Dilaksanakannya proses pendaftaran tersebut tidak semata-mata hanya untuk memenuhi kewajiban administrasi saja. Melainkan dengan dilakukannya proses pendaftaran tersebut maka menimbulkan suatu hubungan hukum antara pesawat udara sipil yang didaftarkan dengan negara tempat pesawat udara sipil didaftarkan. Hubungan hukum tersebut antara lain seperti adanya kewenangan negara tempat pesawat udara sipil didaftarkan atau sering disebut juga sebagai negara kebangsaan untuk menerapkan yurisdiksinya dalam bentuk hak, kewajiban serta tanggung jawab negara terhadap pesawat udara sipil yang memperoleh status kebangsaan negaranya. Dalam hal ini, hak negara yang dimaksud adalah hak negara untuk menerapkan yurisdiksinya diatas pesawat udara yang didaftarkan di negaranya. Maksud dari penerapan yurisdiksi tersebut adalah negara berwenang untuk memberlakukan hukumnya terhadap pesawat udara tersebut seolah-olah pesawat udara tersebut merupakan bagian daripada wilayah negaranya. Ketentuan-ketentuan yang berlaku tersebut pesawat udara tersebut merupakan bentuk dari kewajiban serta tanggung jawab dari negara 
kebangsaan untuk melindungi pesawat udara sipil yang memiliki status kebangsaan negaranya. ${ }^{20}$

\section{Tanggung Jawab Iran Terhadap Penembakan Pesawat Sipil Ukraina ditinjau dari Hukum Internasional Yang Menimbulkan Peran Para Pihak Untuk Mengatur Rute Keselamatan Dalam Penerbangan Sipil.}

Pada hari Rabu, 8 Januari 2020 pesawat sipil milik Ukraina dengan pesawat maskapai Ukrainian International Airlines yang ditembak oleh Iran menggunakan rudal ketika melewati kawasan sensitif di sekitar markas Garda Revolusi Iran. Pesawat jenis Boeing 737-800 jatuh sesaat setelah lepas landas dari Bandara Internasional Imam Khomeini di Teheran.Penerbangan Ukraine Airlines ini terbang dari Bandar Udara Internasional Imam Khomeini, Teheran ke Bandar Udara Boryspil di Kiev. ${ }^{21}$

Pesawat itu membawa 167 penumpang dan 9 awak termasuk 15 anak-anak. Penerbangan 752 lepas landas pada pukul 06.12 waktu setempat dan diperkirakan mendarat di Kiev pada pukul 08.00 waktu Ukraina. Beberapa saat kemudian pesawat terjatuh. Menurut data, ketinggian terakhir adalah 2.416 meter (7.923 kaki) di atas permukaan laut dengan kecepatan udara sekitar 260 knot. Kecelakan itu terjadi sekitar empat jam setelah Iran meluncurkan serangan balasan kepada Amerika Serikat atas pembunuhan Mayor Jendral Qasem Soleimani. ${ }^{22}$

20 Alyssa Adrianti. Tinjauan Hukum Mengenai Pendaftaran Pesawat Udara Sipil di Indonesia Berdasarkan Konvensi Chicago 1944 dan UU No 1 Tahun 2009 Tentang Penerbangan. DIPONEGOROLAW JOURNAL Volume 6 Nomor 2. Tahun 2017.

21 Tim BBC Indonesia,'Penembakan pesawat Ukraina. Media Iran: 'Malu' dan taktermaafkan. Diakses dari https:/www.bbc.com/indonesia/dunia-51081065. Diakses pada 30 Januari 2020 pukul 09.52 WIB

22 Tim BBC Indonesia. Ibid. 
Media Iran memberitahukan bahwa tidak ada penumpang yang selamat ketika pesawat ini jatuh pada pukul 06.22 waktu setempat. Biasanya kasus penembakan pesawat melibatkan lebih dari 1 negara. Seperti pada kasus ini tidak hanya melibatkan Iran yang melakukan dan Ukraina yang memiliki pesawat saja melainkan Kanada juga turut campur dikarenakan korban dari tragedi ini karena sebanyak 63 korban adalah warga negara Kanada. ${ }^{23}$

Ketua komisi kecelakaan di ICAO Iran menyatakan bahwa mereka tidak menerima pesan darurat dari pesawat sebelum kecelakaan tersebut. Disebutkan bahwa kotak hitam pesawat telah ditemukan (flight data recorder dan cockpit voice recorder) tetapi ICAO menolak untuk menyerahkannya ke pihak Boeing. ${ }^{24}$

Juru bicara ICAO mengatakan belum jelas ke negara mana kotak hitam tersebut akan dikirim sehingga data nya dapat dianalisis.Pada tanggal 9 Januari 2020, kotak hitam dilaporkan oleh penyelidik Iran telah rusak. Beberapa sumber intelijen open-sorce ${ }^{25}$ menemukan bukti bahwa pesawat sipil itu terkena rudal. ${ }^{26}$ Pada 10 Januari 2020, Angkatan Bersenjata Republik Iran mengakui bahwa mereka yang telah menembak jatuh pesawat sipil milik Ukraina tersebut karena tidak sengaja mengidentifikasi pesawat tersebut sebagai musuh. Selama tiga hari, Iran membantah tudingan bahwa tembakan misilnya telah menyebabkan jatuhnya pesawat tersebut. Iran menyebut peristiwa itu terjadi akibat kesalahan salah satu tentara mereka. Alasannya dikarenakan pesawat maskapai Ukrainian International Airlines melintasi kawasan yang

23 https://id.wikipedia.org/wiki/Ukraine_International_Airlines_Pe nerbangan_752 diakses 26 Agustus 2020 pada 20.10 WIB.

24 https://www.bbc.com/news/world-middle-east-51047006. diakses pada 26 Agustus 2020 pada 19.25 WIB

25 Open Source Intelligence(OSINT) adalah pengumpulan dan analisis informasi yang dikumpulkan dari publik atau sumber terbuka.

26

Ibid. 
sedang berkonflik di sekitar markas Garda Revolusi Iran. Angkatan bersenjata Iran juga menyebut akan menindak para pihak yang bertanggung jawab atas kejadian itu secara transparan. ${ }^{27}$

Brig-Gen Amir Ali Hajizadeh Komandan Pengawal Revolusi Iran menyatakan bahwa oknum yang melakukan hal ini akan bertanggung jawab penuh atas kecelakaan tersebut. Dia juga mengatakan permintaan telah dibuat untuk zona larangan terbang di daerah tersebut sebelum insiden tetapi karena alasan yang tidak jelas permintaan ini ditolak. ${ }^{28}$

Meskipun suatu negara mempunyai kedaulatan atas dirinya, tidak lantas negara tersebut dapat menggunakan kedaulatannya tanpa menghormati kedaulatan negara-negara lain. Hukum internasional telah mengatur bahwa kedaulatan tersebut berkaitan dengan kewajiban untuk tidak menyalahgunakan kedaulatan itu sendiri, karena apabila suatu Negara menyalahgunakan kedaulatannya, maka negara tersebut dapat dimintai suatu pertanggungjawaban atas tindakan dan kelalaiannya.

Harus diingat juga bahwa Paris Konvensi 1919 sudah secara tegas menyatakan prinsip kedaulatan bukannya konsep kebebasan udara. Kontrol lalu lintas udara dan layanan navigasi udara untuk Iran dan wilayah sekitarnya di wilayah tersebut masih diberikan di bawah otoritas Iran, oleh karena itu, tidak perlu dipertanyakan lagi bahwa Iran bertanggung jawab atas hal itu memastikan keamanan operasi penerbangan sipil di wilayah udara yang berdaulat.

Iran, yang merupakan anggota Organisasi Penerbangan Sipil Internasional, berkewajiban memastikan pengelolaan ruang udara atas wilayah ini. Standar dan rekomendasi dalam

27 Ibid.

28 https://www.npr.org/2020/07/12/890194877/iranian-report-detailschain-of-mistakes-in-shooting-down-ukrainian-passenger-pl diakses pada 3 Agustus 2020 pada 10.43 WIB

Uti Possidetis: Journal of International Law, Vol. 1, No. 3 (2020) 
penerbangan sipil internasional berada dalam Lampiran 11 berlaku di bagian wilayah udara tersebut di bawah yurisdiksi Negara pihak pada Persetujuan dimana layanan lalu lintas udara disediakan dan juga dimanapun Negara Peserta menerima tanggung jawab menyediakan layanan lalu lintas udara di laut lepas atau di wilayah udara dari kedaulatan yang tidak ditentukan. ${ }^{29}$

Iran yang tengah berkonflik dengan Amerika Serikat seharusnya mengabulkan permintaan Gen Amir Ali Hajizadeh Komandan Pengwal Revolusi Iran untuk membuat zona larangan terbang di daerah tersebut. Agar pesawat yang ingin melewati daerah tersebut tidak memasuki wilayah udara yang tengah berkonflik itu.Mengenai pertanggungjawaban atas penembakan pesawat sipil milik Ukraina ini yang didasarkan pada teori kepemilikan ruang udara ( The Air Sovereignity) menyatakan bahwa subjacent state yang dalam kasus ini adalah Iran berdaulat penuh atas wilayah udara di atasnya maka praktis ini merupakan tanggung jawab penuh Iran untuk melindungi pesawat apapun yang melintasi wilayah udaranya.

Sebagaimana diatur dalam Pasal 44 huruf (a) Konvensi Chicago 1944 bahwa penggunaan senjata sebagai media untuk memaksa pesawat udara yang melakukan pelanggaran wilayah kedaulatan tidak sejalan dengan prinsip safety first dalam hukum udara internasional. ${ }^{30}$

Pertanggungjawaban hukum pelaku sesuai dengan peristiwanya dapat terkait dengan ketentuan-ketentuan hukum internasional yang diatur dalam Pasal 3 tambahan Konvensi Chicago 1944, yang berbunyi sebagai berikut :

29 Dewa Gede Sudika Mangku. Tanggung Jawab Negara Terhadap Penembakan Pesawat MH17 Diatas Wilayah Konflik Bersenjata Antara Ukraina dan Rusia Berdasarkan Hukum Internasional. Jurnal Komunitas Yusticia. Volume 14. Nomor 1. Juni 2019. hal. 25-33.

30 Bambang Widarto. Pertanggungjawaban Hukum Dalam Peristiwa Penembakan Pesawat Udara Sipil Ditinjau Dari Aspek Hukum Internasional. Jurnal Yuridis. Volume 1 No. 2 Desember 2014. 
a) The contracting States recognize that every State must refrain from resorting to the use of weapons against civil aircraft in flight and that, in case of interception, the lives of persons on board and the safety of aircraft must not be endangered. This provision shall not be interpreted as modifying in any way the rights and obligations of States set forth in the Charter of the United Nations.

b) The contracting States recognize that every State, in the exercise of its sovereignty, is entitled to require the landing at some designated airport of a civil aircraft flying above its territory without authority or if there are reasonable grounds to conclude that it is being used for any purpose inconsistent with the aims of this Convention; it may also give such aircraft any other instructions to put an end to such violations. For this purpose, the contracting States may resort to any appropriate means consistent with relevant rules of international law, including the relevant provisions of this Convention, specifically paragraph a) of this Article. Each contracting State agrees to publish its regulations in force regarding the interception of civil aircraft.

c) Every civil aircraft shall comply with an order given in conformity with paragraph b) of this Article. To this end each contracting State shall establish all necessary provisions in its national laws or regulations to make such compliance mandatory for any civil aircraft registered in that State or operated by an operator who has his principal place of business or permanent residence in that State. Each contracting State shall make any violation of such applicable laws or regulations punishable by severe penalties and shall submit the case to its competent authorities in accordance with its laws or regulations

d) Each contracting State shall take appropriate measures to prohibit the deliberate use of any civil aircraft registered in that State or operated by an 
operator who has his principal place of business or permanent residence in that State for any purpose inconsistent with the aims of this Convention. This provision shall not affect paragraph a) or derogate from paragraphs b) and c) of this Article.

Keselamatan paling penting harus diarahkan pada kalimat pertama dan kalimat kedua pasal 3 tambahan.Kewajiban di kalimat pertama di paragraf (a) jauh lebih kaku daripada di artikel pertama. Ketika melihat lebih dekat pada paragraf (a) sepertinya itu adalah keselamatan pesawat dan nyawa orang-orang di dalamnya yang penting. Pentingnya paragraf (a) kemudian ditekankan dalam paragraf (b) dan Negara-negara pihak harus menahan diri untuk tidak menggunakan senjata terhadap pesawat sipil. Pembatasan dan pelarangan ini didasarkan pada alasan kebutuhan militer atau keamanan publik. Jika didalam suatu periode yang membahayakan, negara dapat membatasi atau menutup seluruh bagian dari wilayah udaranya. Zona yang dilarang untuk dilewati harus dikomunikasikan secepatnya kepada negara lainnya dan kepada ICAO. ${ }^{31}$

Menggunakan senjata pada penerbangan sipil adalah hal yang dilarang meskipun pesawat tersebut adalah ancaman ataupun melanggar wilayah kedaulatan negara kolong. Kedaulatan penuh dan eksklusif memungkinkan negara untuk mengatur dan mengelola wilayah udaranya sendiri. Sehingga setiap pesawat udara sipil yang akan melewati ataupun mendarat di wilayah udara suatu negara harus meminta ijin terlebih dahulu kepada negara kolong wilayah udara tersebut. Untuk membantu Konvensi Chicago 1944 diadopsilah

31 Arland Yoga. Peran International Civil Aviation Organization dalam Penanganan Kasus Penembakan Penerbangan Sipil Internasional Studi Kasus: Penembakan Pesawat Malaysia Airlines MH17 Tahun 2014. Jurnal Hubungan Internasional. Vol 4 No. 2. 2018 hal. 242. 
rekomendasi standar dan teknis yang terkait dengan aspek penerbangan. ${ }^{32}$

Standar dan Teknis ini diadopsi kedalam Annex 13 yang dibuat oleh ICAO. Annex 13 berisi sebagai berikut :

"The causes of an aircraft accident or serious incident must be identified in order to prevent repeated occurrences. The identification of causal factors is best accomplished through a properly conducted investigation. To emphasise this point, Annex 13 states that the objective of the investigation of an accident or incident is prevention."

"Annex 13 provides the international requirements for the investigation of aircraft accidents and incidents. It has been written in a way that can be understood by all participants in an investigation. As such, it serves as a reference document for people around the world who may be called on, often without any lead time, to deal with the many aspects involved in the investigation of an aircraft accident or serious incident. As an example, the Annex spells out which States may participate in an investigation, such as the States of Occurrence, Registry, Operator, Design and Manufacture. It also defines the rights and responsibilities of such States."

Annex 13 memberikan rincian mengenai negara-negara mana saja yang punya hak untuk berpartisipasi dalam melakukan investigasi dalam sebuah kecelakaan pesawat. Dan dalam kasus ini Kanada, Ukraina, Swedia, Afghanistan dan Inggris dapat berpartisipasi dalam investigasi ini karena ada warga negara mereka yang menjadi korban dalam kecelakaan

32 Baiq Setian. Konsep Kedaulatan Negara di Ruang Udara dan Upaya Penegakan Pelanggaran Kedaulatan oleh Pesawat Udara Asing. Jurnal Konstitusi. Volume 14 Nomor 3. September 2017. hal 494. 
ini. Annex 13 membahas mengenai kecelakaan pesawat dan investigasinya. Pada annex tersebut dijelaskan mengenai tanggung jawab suatu negara ketika melaksanakan investigasi akan kecelakaan pesawat. Penggolongan negara dalam annex 13 ini dibagi kedalam 5 kategori yang diantaranya adalah State of Occurance, State of Registry, State of the Operator, State of Design, dan State of Manufacture. ${ }^{33}$

ICAO biasanya tidak berpartisipasi dalam penyelidikan kecelakaan pesawat, kecuali jika Negara yang memiliki kewenangan sesuai dengan Annex 13 meminta bantuannya secara langsung. Dalam keadaan luar biasa tersebut, bantuan tersebut biasanya melibatkan ICAO yang bertindaksebagai pengamat resmi dan / atau mengklarifikasi berbagai persyaratan Annex 13 bila diminta. ${ }^{34}$

ICAO biasanya tidak berpartisipasi dalam penyelidikan kecelakaan pesawat, kecuali jika Negara yang memiliki kewenangan sesuai dengan Annex 13 meminta bantuannya secara langsung. Dalam keadaan luar biasa tersebut, bantuan tersebut biasanya melibatkan ICAO yang bertindaksebagai pengamat resmi dan / atau mengklarifikasi berbagai persyaratan Annex 13 bila diminta. ${ }^{35}$ Dalam kasus penembakan ini Piagam PBB yang dianggap sebagai puncak hukum internasional memiliki kerangka khusus kondisi tentang penggunaan kekuatan. Secara khusus, Pasal 2 ayat 4 berbunyi: "the Charter prohibits the threat or use of force and calls on all Members to respect the sovereignty, territorial

33 http://www.ilmuterbang.com/artikel-mainmenu-29/keselamatanpenerbangan-mainmenu-48/795-bab-2-annex-13-dari-konvensichicago-bagian-1 diakses pada 20 Agustus 2020 pada 20.35 WIB .

34 http://www.ilmuterbang.com/artikel-mainmenu-29/keselamatanpenerbangan-mainmenu-48/796-bab-2-annex-13-dari-konvensichicago-bagian-2. diakses pada 20 Agustus 2020 pada 22.37 WIB http://www.ilmuterbang.com/artikel-mainmenu-29/keselamatanpenerbangan-mainmenu-48/796-bab-2-annex-13-dari-konvensichicago-bagian-2. diakses pada 20 Agustus 2020 pada 22.37 WIB

Uti Possidetis: Journal of International Law, Vol. 1, No. 3 (2020) 
integrity and political independence of other States". Dalam Pasal ini mewajibkan semua negara anggota untuk menahan diri dalam hubungan internasional mereka dari ancaman atau penggunaan kekerasan integritas teritorial atau kemerdekaan politik negara mana pun, atau dengan cara lain apa pun tidak konsisten dengan Tujuan Perserikatan Bangsa-Bangsa.

Penggunaan kekerasan terhadap pesawat sipil, dalam hukum internasional merupakan penggunaan kekuatan dalam arti aturan ini. Jika Kanada atau negara lain memang memilih untuk menerapkan hukum internasional untuk mencari keadilan untuk warganya dalam hal ini, Iran kemungkinan akan menggunakan Pasal 51 Piagam PBB, yang memverifikasi hak pertahanan diri negara anggota. Pertanyaan tentang pertahanan diri muncul dalam hal ini kasus karena penembakan pesawat 752 terjadi tak lama setelah konflik terjadi ketegangan antara Amerika Serikat dan Iran (meskipun di luar wilayah Iran) serta Amerika Serikat baru saja melakukan pembunuhan yang ditargetkan dengan serangan pesawat tak berawak di Baghdad pada komandan Pasukan Quds Soleimani, dan Iran menanggapi dengan menembakkan rudal jelajah ke pangkalan Amerika Serikat di Irak. Tetapi argumen pembelaan diri mungkin tidak dapat diterapkan dalam hal ini. ${ }^{36}$ Mengingat bahwa Penerbangan 752 Ukrainia Airlines ditembak jatuh hanya beberapa jam setelah Iran menyerang dua pangkalan Amerika Serikat di Irak, Iran bisa membantah bahwa kesalahan manusia yang menyebabkan itu karena salah mengidentifikasi pesawat Ukraina sebagai rudal Amerika setidaknya sebagian dapat dijelaskan oleh konteks militer. Tapi pesawat sipil tidak boleh terancaman, tidak

36 Punsara Amarasinghe. International Law and the Downing of Ukraine International Airlines Flight 752. BESA Center Perspectives Paper No. 1. Januari 2020. hal 414. 
peduli apa yang terjadi di wilayah tersebut. Pesawat sipil itu jatuh sebagai akibat dari kesalahan yang tragis. ${ }^{37}$

Dalam situasi khusus ini, tanggung jawab Iran tampak lebih berat. Kesalahan Iran meningkat dengan upaya awalnya untuk menghalangi penyelidikan kecelakaan tersebut dan untuk menggambarkannya secara menipu sebagai akibat dari kesalahan teknis. Lebih penting lagi, pesawat tidak akan pernah tertembak jatuh seandainya otoritas Iran menutup wilayah udara negara hari itu. Tindakan pencegahan yang wajar mengingat kemungkinan konflik yang masih bergulir dengan Amerika Serikat setelah Serangan rudal Iran.

Langkah paling bijak Iran, sebelum tindakan hukum apa pun oleh Kanada, Ukraina, Swedia, atau Inggris, mungkin mengakui tanggung jawab dan berkomitmen untuk membayar ganti rugi bagi nyawa yang hilang. Serta melakukan investigasi yang adil, memberikan reparasi, dan meminta maaf, Iran dapat mengurangi status negaranya ke isolasi yang lebih besar dalam lingkup Internasional.

\section{Simpulan}

Berdasarkan pembahasan tersebut dapat dihasilkan simpulan sebagai berikut :

1. Pengaturan hukum udara internasional terkait kewajiban para pihak untuk mengatur keselamatan penerbangan sipil yang menlewati wilayah udaranya adalah bahwa sesuai dengan Pasal 1 Konvensi Chicago 1944 bahwa negara berdaulat penuh dan utuh atas wilayah udara diatasnya, negara secara otomatis juga wajib menjaga keamanan dan keselamatan pesawat yang melintasi wilayah udaranya. Hal yang dapat negara lakukan adalah pertama menetapkan zona larangan terbang apabila

37 Punsara Amarasinghe. Ibid.

Uti Possidetis: Journal of International Law, Vol. 1, No. 3 (2020) 
di wilayah udara negara tersebut sedang terjadi sesuatu dan tidak memungkinkan untuk dilewati oleh pesawat sipil dan kedua memberikan navigasi penerbangan yang jelas sehingga dapat menjamin keselamatan dan keamanan pesawat sipil yang melewati wilayah udara negara tersebut.

2. Iran yang telah menembak jatuh pesawat sipil milk Ukraina yang sedang melewati wilayahnya bertanggung jawab penuh atas hal itu. Sesuai dengan Pasal 1 dalam Konvensi Chicago 1944. Iran seharusnya menetapkan zona larangan terbang di wilayah udaranya ketika sedang berkonflik sehingga pesawat sipil milik Ukraina itu tidak memasuki wilayah tersebut.

3. Iran juga seharusnya menahan diri dan tidak menggunakan senjata terhadap pesawat sipil. Karena pesawat sipil tidak boleh terancaman, tidak peduli apa yang terjadi di wilayah tersebut. Prinsip safety must always come first harus diterapkan dalam keadaan apapun. Keselamatan penumpang dalam pesawat sipil adalah jaminan yang absolut. Apapun yang terjadi di wilayah tersebut tetap harus menempatkan keamanan dan keselamatan pada derajat teratas. Dan karena Iran gagal melakukan itu, maka Iran dituntut untuk melakukan pertanggungjawaban penuh atas perbuatannya.

Adapun saran dalam pembahasan di atas adalah sebagai berikut :

1. Sesuai dengan Pasal 1 Konvensi Chicago 1944 bahwa negara berdaulat penuh dan utuh atas wilayah udara diatasnya, negara secara otomatis juga wajib menjaga keamanan dan keselamatan pesawat yang melintasi wilayah udaranya. Negara pihak seharusnya mematuhi Konvensi Chicago 1944 karena di dalam Konvensi itu merupakan peraturan yang menyeluruh tentang bagaimana Negara pihak 
harus mengatur dan melindungi keselamatan penerbangan sipil yang melewati wilayah udaranya.

2. Konvensi Chicago 1944 dan juga ICAO sudah menjamin keselamatan dan keamanan dalam penerbangan. Iran sebagai Negara kolong seharusnya dapat lebih memperhatikan keselamatan pesawat sipil yang melewati wilayah udaranya. Terlepas dari apapun yang terjadi antara Iran dan Amerika Serikat. Iran yang menembak rudal nya ke pesawat sipil Ukrainian Airlines dan menyebabkan korban jiwa yang tidak sedikit harus bertanggung jawab atas perbuatannya. Iran yang gagal dalam menjaga keselamatan pesawat sipil yang melewati wilayah udaranya harus bertanggung jawab penuh dengan cara melakukan perbaikan (reparation) atas kerugian material ataupun moral yang diakibatkan oleh perbutannya. Di masa yang akan datang diperlukan ketegasan dan sanksi hukum yang nyata atas pertanggungjawaban negara yang melakukan kelalaian dan menyebabkan kerugian dalam rute penerbangan sipil internasional serta perlunya meningkatkan kerja sama dengan berbagai pihak agar keselamatan dan keamanan dalam penerbangan internasional bisa tercapai.

\section{Referensi}

\section{Instrumen Hukum}

Chicago Convention on International Civil Aviation 1944

Convention and Certain Other Acts Committe on Board Aicraft 1963

Paris Convention of 1919

The Montreal Convention 1999

\section{Buku}


Abdurrasyid, Priyatna. Kedaulatan Negara Di Ruang Udara. Fikahati Aneska, Jakarta, 2003.

Adolf, Huala. Aspek-Aspek Negara Dalam Hukum Internasional. CV Keni Media. Bandung. 2011.

Kusumaatmadja, Mochtar dan Etty R. Agoes. Pengantar Hukum Internasional. PT. Alumni. Bandung 2003.

Martono, H.K.dan Amad Sudiro,Hukum Udara Nasional dan Internasional.Cet.Pertama.Raja Grafindo Persada. Jakarta. 2012.

Marzuki, Peter Mahmud. PenelitianHukum.

Cet.Kesembilan.Kencana,Jakarta,2014.

Nasution,Bahder Johan. Metode Penelitian Ilmu Hukum. Cet.Kedua. Mandar Maju. Bandung. 2016.

Shaw QC, Malcolm N. Hukum Internasional. Nusa Media, Bandung. 2008.

Soekanto, Soerjono. Peneitian Hukum Normatif : Suatu

Tinjauan Singkat, PT.Raja Grafindo Persada, Jakarta, 2003.

Starke, JG. Pengantar Hukum Internasional. Edisi Kesepuluh, Sinar Grafika. Jakarta. 2006.

Suherman, E. Hukum Udara Indonesia dan Internasional. Alumni. Bandung. 1983.

Thontowi, Jawahir dan Pranoto Iskandar.Hukum Internasional Kontemporer.Cet. Pertama. Refika Aditama. Yogyakarta. 2006.

Wiradipradja, E. Saefullah. Tanggung Jawab Pengangkut dalam Hukum Pengangkut Udara Internasional dan Nasional. Liberty. Yogyakarta. 1989.

\section{Artikel/Jurnal}

Adrianti, Alyysa, "Tinjauan Hukum Mengenai Pendaftaran Pesawat Udara Sipil di Indonesia Berdasarkan Konvensi Chicago 1944 dan UU No 1 Tahun 2009 
Tentang Penerbangan" DIPONEGORO LAW JOURNAL Volume 6 Nomor 2. Tahun 2017.

Mangku, Dewa Gede Sudika,"Tanggung Jawab Negara Terhadap Penembakan Pesawat MH17 Diatas Wilayah Konflik Bersenjata Antara Ukraina dan Rusia Berdasarkan Hukum Internasional". Jurnal Hukum. Vol.14 No.1. 2019.

Puji Lestari, Endang, "Rekonsepsi Hak Penguasaan Negara Atas Wilayah Udara Di Tengah Kebijakan Liberalisasi Penerbangan". Jurnal Rechts Vinding. Volume 4 Nomor 2. Agustus 2015.

Setiani, Baiq,"Konsep Kedaulatan Negara di Ruang Udara dan Upaya Penegakan Pelanggaran Kedaulatan oleh Pesawat Udara Asing". Jurnal Konstitusi, Volume 14Nomor 3. September 2017. Jakarta. 2017.

Simatupang, Andika Immanuel. "State Responsibility Over Safety Security On Air Navigation Of Civil Aviation In International Law". Jurnal Hukum Internasional Vol 13 No 2 2016. Jakarta. 2016.

Universitas Indonesia. LPHI "International Law Making", Jurnal Hukum Internasional Vol 6 No 4 Jakarta. 2009.

Untung, Heribertus, "Pertanggungjawaban negara terhadap pencemaran udara akibat kebakaran hutan di Indonesia tahun 1997". Jurnal Hukum Lingkungan,2001.

Widarto, Bambang, "Pertanggungjawaban Hukum Dalam

Peristiwa Penembakan Pesawat Udara Sipil Ditinjau

Dari Aspek Hukum Internasional". Jurnal Yuridis, Volume 1 No. 2 Desember 2014.

Yoga, Arland."Peran International Civil Aviation Organization dalam Penanganan Kasus Penembakan Penerbangan Sipil Internasional Studi Kasus: Penembakan Pesawat Malaysia Airlines MH17 Tahun 2014". Jurnal Hubungan Internasional,Vol 4 No. 2,2018.Jakarta,2018. 


\section{Karya Ilmiah}

Amarasinghe, Punsara. "International Law and the Downing of Ukraine International Airlines Flight 752, International Law and the Downing of Ukraine International Airlines Flight 752". BESA Center Perspectives Paper No. 1,414. January 21. Israel. 2020

Jasiuka, Ewa. "The responsibility of a State in the shooting down of Malaysian Airlines flight MH17", 8th International Conference on Air Transport - INAIR 2019 GLOBAL TRENDS IN AVIATION. Polandia. 2019.

\section{Laman}

https://Databoks.Katadata.Co.Id/Datapublish/2019/12/12/Ti

ngkat-Kecelakaan Penerbangan-Global

https://www.bbc.com/indonesia/dunia-51081065

https://news.detik.com/internasional/d-4855221/iran-tak-

sengaja-tembak-jatuh pesawat-sipil-ukraina-ini-kata-

pm-kanada

https://kumparan.com/gulardi-nurbintoro/4-hal-yang-wajib-

diketahui-tentang-mahkamah-internasional-

1550672851698861560

https://en.wikipedia.org/wiki/International Civil Aviation Or

ganization

https://www.icj-cij.org/en/jurisdiction

https://en.wikipedia.org/wiki/International Civil Aviation Or

ganization

https://en.m.wikipedia.org/wiki/Air battle over Merklín https://www.britannica.com/topic/International-Civil-

Aviation-Organization

https://id.wikipedia.org/wiki/Pesawat penumpang_sipil\#Seja

rah dan perkembangannya diakses pada 18 Juni 2020

pukul 22.00 WIB

https://suduthukum.com/2017/02/sejarah-hukum-udara-

internasional.html

Uti Possidetis: Journal of International Law, Vol. 1, No. 3 (2020) 
https://www.bbc.com/news/world-middle-east-51047006 https://id.wikipedia.org/wiki/Ukraine International Airlines

Penerbangan 752

https://www.npr.org/2020/07/12/890194877/iranian-

report-details-chain-of-mistakes-in-shooting-down-

ukrainian-passenger-pl

http://www.ilmuterbang.com/artikel-mainmenu-

29/keselamatan-penerbangan-mainmenu-48/795-

bab-2-annex-13-dari-konvensi-chicago-bagian-1

http://www.ilmuterbang.com/artikel-mainmenu-

29/keselamatan-penerbangan-mainmenu-48/796-

bab-2-annex-13-dari-konvensi-chicago-bagian-2 